\title{
KEDUDUKAN HAKIM AD-HOC PADA PENGADILAN TIPIKOR (TINDAK PIDANA KORUPSI) DITINJAU DARI UNDANG-UNDANG NOMOR 48 TAHUN 2009 TENTANG KEKUASAAN KEHAKIMAN
}

\author{
TITIN APRIANI \\ Fakultas Hukum UNMAS Denpasar PSDKU Mataram \\ e-mail: titinapriani97@yahoo.com
}

\begin{abstract}
ABSTRAK
Penelitian ini merupakan penelitian pustaka yaitu menggunakan data berupa buku-buku, undangundang, artikel, jurnal dan literature lain yang berkaitan denga judul, sedangkan teknik dan pengumpulan data adalah dengan mengumpulkan berbagai ide, teori dan konsep dari berbagai literature yang menitik beratkan pada proses perbandingan antara dalil-dalil atau undang-undang lainnya. Hasil penelitian disimpulkan bahwa putusan Mahkamah Konstitusi terhadap kedudukan hakim ad hoc tersebut sudah tepat karena memberikan kedudukan yang sama terhadap suatu hal yang berbeda justru menimbulkan ketidak adilan.

Selain memiliki kewenangan memerikasa, mengadili, dan memutus perkara tidak pidana korupsi, hakim adhoc juga memiliki kewenangan memeriksa perkara tidak pidana pencucian uang yang tindak pidana asalnya adalah tindak pidana korupsi. Jadi disini korupsi sebagai tindak pidana asal yang sering disebut sebagai predicate crimes. Tak kalah pentingnya bahwa peran dan kewenangan hakim adhoc spesialisasi dalam kaitan pasal 6 huruf c kewenanan pengadilan tipikor untuk menangani tindak yang secara tegas dalam undang-undang lain ditentukan sebagai tindak pidana korupsi
\end{abstract}

Kata kunci : Kedudukan Hakim Ad-Hok, pengadilan tipikor, kekuasaan Kehakiman

\section{ABSTRACT}

This research is a library research that uses data in the form of books, laws, articles, journals and other literature related to the title, while the technique and data collection is by collecting various ideas, theories and concepts of various literature that are centered on the process of comparison between the evidence or other laws. The results of the study concluded that the ruling of the Constitutional Court against the position of the ad hoc judge is appropriate because it gives the same position on a different matter precisely caused injustice.

In addition to having the authority to check, prosecute, and break the criminal corruption, adhoc judges also have the authority to examine the criminal case of money laundering that the original criminal act is a corruption crime. So here corruption as the original criminal act is often referred to as predicate crimes. It is no less important that the role and authority of the adhoc judge specialising in the association of article 6 letter $c$ The authority of the Court of Law to handle a strict follow-up in another law is determined as a corruption criminal act

Keywords: Position of Judge Ad-Hok, Corruption Court, Judicial Authority

\section{PENDAHULUAN}

\section{Latar Belakang}

Indonesia merupakan Negara hukum (rechtsstaat) yang mempunyai dasar ideologi Pancasila. Berdasarkan Pancasila yang berbunyi "keadilan sosial bagi seluruh rakyat Indonesia" dijelaskan bahwa setiap rakyat Indonesia di mata hukum kedudukannya satu sama lain adalah sama. Sehingga setiap orang 
mempunyai hak yang sama untuk mendapat suatu keadilan. Baik itu suatu keadilan yang berasal dari lingkungan sekitar maupun keadilan yang berasal dari pemerintah.

Kejahatan di Indonesia dari tahun ke tahun dari segi modus, macam, jenis dan lain-lain sudah semakin berkembang khususnya kejahatan tindak pidana korupsi yang telah masuk sampai ke seluruh lapisan kehidupan masyarakat. Korupsi merupakan suatu momok yang menakutkan karena dengan adanya korupsi akan membawa dampak yang tidak hanya sebatas kehidupan perekonomian nasional saja tetapi juga meghambat pembangunan nasional serta memberi dampak pada kehidupan berbangsa dan bernegara. Kejahatan tindak pidana korupsi ini merupakan salah satu kejahatan luar biasa (extra ordinary crime) dimana dalam menyelesaikan perkara ini membutuhkan suatu penanganan khusus dan cara-cara yang luar biasa untuk mengatasinya.

Penegakan hukum di Indonesia yang selama ini dilakukan untuk mempersempit ruang gerak para koruptor secara konvensional terbukti telah mengalami berbagai rintangan sehingga membuat masyarakat tidak percaya terhadap masa depan penegakan hukum di Indonesia khususnya dalam hal pemberantasan korupsi. Menurunnya kepercayaan ini disebabkan adanya aparat penegak hukum yang nakal sehingga timbul adanya mafia peradilan (judicial corruption) di lingkungan peradilan. Oleh karena itu, diperlukan metode penegakan hukum dalam suatu badan khusus yang mempunyai kewenangan luas, independen serta bebas dari kekuasaan manapun dalam upaya pemberantasan tindak pidana korupsi yang efektif dan profesional.

Setelah masa reformasi perlu adanya fasilitas dan sarana penegakan hukum yang berbeda dalam upaya pemberantasan tindak pidana korupsi. Dengan berlakunya Pasal 43 ayat (1) Undang-Undang Nomor 31 Tahun 1999 tentang Pemberantasan Tindak Pidana Korupsi, bahwa dalam waktu paling lambat 2 (dua) tahun sejak Undang-Undang Nomor 31 Tahun 1999 maka dibentuklah suatu lembaga Komisi Pemberantasan Korupsi yang kemudian diperbaharui dengan Undang Undang Nomor 30 Tahun 2002.

\section{Rumusan Masalah}

1. Bagaimana kedudukan hakim Ad-Hoc pada Pengadilan Tipikor (Tindak Pidana Korupsi) ditinjau dari Undang-Undang No. 48 Tahun 2009 tentang kekuasaan kehakiman

2. Bagaimana implikasi dari kedudukan hakim Ad-Hoc pada Pengadilan Tipikor (Tindak Pidana Korupsi)

\section{Tujuan dan Manfaat Penelitian}

\section{Tujuan Penelitian}

1. Tujuan Obyektif

a. Untuk mengetahui latar belakang terbentuknya hakim pengadilan tindak pidana korupsi di dalam sistem kekuasaan kehakiman.

b. Untuk mengetahui fungsi dari keberadaan hakim ad hoc di dalam pengadilan tindak pidana korupsi berdasarkan sistem kekuasaan kehakiman di Indonesia

2. Tujuan Subyektif

a. Untuk menambah wawasan dan pengetahuan dibidang peradilan khususnya mengenai latar belakang kedudukan hakim ad hoc Pengadilan Tindak Pidana Korupsi di dalam sistem kekuasaan kehakiman dan implikasi yuridis dari fungsi keberadaan hakim ad hoc;

b. Sebagai bentuk kepedulian guna pengembangan hukum terutama yang menyangkut mengenai kedudukan Hakim Ad Hoc Pengadilan Tindak Pidana Korupsi di dalam sistem kekuasaan kehakiman;

\section{Manfaat Penelitian}

1. Manfaat Teoritis

a. Hasil penelitian ini mampu menyumbangkan pemikiran bagi pengembangan ilmu hukum pada umumnya

b. Memperkaya referensi dan literatur dalam dunia kepustakaan tentang kedudukan Hakim Ad Hoc pada Pengadilan Tindak Pidana Korupsi menurut sistem kekuasaan kehakiman; 


\section{Manfaat Praktis}

Dapat mengembangkan kemampuan berpikir dan diharapkan hasil dari penelitian ini dapat digunakan sebagai bahan pertimbangan Pemerintah Indonesia supaya lebih meningkatkan

kualitas dan peranan hakim ad hoc pada Pengadilan Tindak Pidana Korupsi dalam menegakkan keadilan bagi seluruh rakyat Indonesia.

\section{METODE PENELITIAN}

Pendekatan yang relevan dengan penelitian hukum ini adalah pendekatan undang-undang (statute approach). Pendekatan undang-undang dilakukan dengan mendekati masalah yang diteliti dengan menggunakan sifat hukum yang normatif, karena dalam penelitian ini hukum dikonsepkan sebagai normanorma tertulis yang dibuat oleh lembaga atau pejabat yang berwenang. Oleh karena itu, pengkajian yang dilakukan hanyalah terbatas pada peraturan

perundang-undangan (tertulis) yang terkait dengan masalah yang diteliti.

Dalam penelitian ini yang digunakan sebagai acuan adalah Undang Undang Nonor 8 Tahun 1981 Tentang Hukum Acara Pidana, Undang Undang Nomor 31 Tahun 1999 sebagaimana yang telah diubah menjadi Undang-Undang Nomor 20 Tahun 2001 Tentang Pemberantasan Tindak Pidana Korupsi, UndangUndang Nomor 30 Tahun 2002 Tentang Komisi

Pemberantasan Tindak Pidana Korupsi, Undang-Undang No 46 Tahun 2009 Tentang Pengadilan Tindak Pidana Korupsi, Undang-Undang Nomor 4 Tahun 2004 sebagaimana yang telah diubah menjadi Nomor 48 Tahun 2009 Tentang Kekuasaan Kehakiman.

Jenis dan Sumber Bahan Hukum Penelitian. Penelitian ini adalah penelitian kepustakaan (normatif), sehingga bahan dari penelitian ini adalah bahan hukum primer dan bahan hukum

sekunder. Sumber data yang digunakan adalah ; a. Bahan hukum primer yang digunakan adalah: UndangUndang Nomor 8 Tahun 1981 Tentang Hukum Acara Pidana, Undang-Undang Nomor 31 Tahun 1999 sebagaimana yang telah diubah menjadi Undang-Undang Nomor 20 Tahun 2001 Tentang Pemberantasan Tindak Pidana Korupsi, Undang-Undang Nomor 30 Tahun 2002 Tentang Komisi Pemberantasan Tindak Pidana Korupsi, Undang Undang No 46 Tahun 2009 Tentang Pengadilan Tindak Pidana Korupsi, UndangUndang Nomor 4 Tahun 2004 sebagaimana yang telah diubah menjadi Nomor 48 Tahun 2009 Tentang Kekuasaan Kehakiman; b. Bahan hukum sekunder, yaitu bahan yang berisi penjelasan mengenai bahan hukum primer yang terdiri dari buku, artikel, majalah, koran, makalah dan lain sebagainya khususnya yang berkaitan dengan penelitian hukum ini; c. Bahan hukum tersier, yaitu bahan hukum yang memberikan petunjuk atau penjelasan terhadap bahan hukum sekunder yang terdiri dari kamus, dan bahan-bahan dari internet.

\section{HASIL DAN PEMBAHASAN}

\section{Kedudukan Hakim Ad-Hoc pada Pengadilan Tipikor (Tindak Pidana Korupsi) ditinjau dari Undang-Undang No. 48 Tahun 2009 tentang kekuasaan kehakiman.}

Undang-Undang Dasar Negara Repubilik Indonesia Tahun 1945 menegaskan bahwa kedaulatan berada ditangan rakyat dan dilaksanakan menurut Undang-Undang Dasar. Ditegaskan pula bahwa negara Indonesia adalah negara hukum. Konsekuensi dari ketentuan yang tercantum dalam Undang-Undang Dasar 1945 adalah segala bentuk yang berkaitan dengan menjalankan tujuan negara Indonesia harus berlandaskan pada peraturan perundang-undangan yang berlaku dan hukum yang hidup dan berkembang dalam masyarakat. Oleh karena itu, untuk mewujudkan tujuan negara sebagai negara hukum, maka dalam mencapai sasarannya, perlu dibentuk sebuah lembaga peradilan yang mempunyai tugas menegakkan hukum di bumi Nusantara ini. Dalam perkembangan ketatanegaraan kita, Undang-Undang yang mengatur mengenai Kekuasaan Kehakiman telah mengalami beberapa kali perubahan yakni Undang-Undang Nomor 14 Tahun 1970 yang diubah dengan Undang-Undang Nomor 4 Tahun 2004 dan diubah dengan Undang-Undang Nomor 48 Tahun 2009 mengenai Undang-Undang tentang Kekuasaan Kehakiman.

Sejalan dengan perubahan tersebut, Indonesia telah resmi memiliki Mahkamah Konstitusi yaitu dengan keluarnya Undang-Undang Nomor 24 Tahun 2003 sebagai pelaksana terhadap Undang-Undang Dasar Pasal 24 Ayat (2) Yang berbunyi: Kekuasaan Kehakiman dilakukan oleh sebuah Mahkamah Agung dan badan peradilan yang berada dibawahnya dalam lingkungan peradilan umum, lingkungan peradilan 
agama, lingkungan peradilan militer, lingkungan peradilan tata usaha negara, dan oleh sebuah Mahkamah Konstitusi.

Sebenarnya apabila kita melihat dan membaca dengan seksama Undang-Undang Dasar Pasal 24 mengenai Kekuasaan Kehakiman, jelas terlihat adanya tumpang tindih kewenangan antara Mahkamah Agung dan Mahkmah Konsitusi yakni terhadap Pasal 24A Ayat (1) dan Pasal 24C Ayat (1). Dimana sebenarnya awal dari maksud pembentukan Mahkamah Konsititusi adalah untuk melindungi produk hukum yakni undang-undang dan peraturan perundang-undangan dibawahnya yang dihasilkan DPR agar tidak berbenturan dengan konstitusi kita dengan dapat mengujinya. Akan tetapi disisi lain Mahkamah Agung masih memiliki kewenangan untuk hal itu yakni menguji peraturan perundang-undangan dibawah undangundang terhadap undang-undang, yang seharusnya hal ini menjadi kewenangan mutlak dari Mahkamah Konstitusi. Maka untuk kedepannya, khususnya ketiga hendak diadakan amandemen kelima Pasal yang mengatur mengenai Kekuasaan Kehakiman harap ditinjau kembali agar jelas kedudukan kewenangan antara dua lembaga tinggi ini, agar terciptanya check and balancies yang baik diantar keduanya.

Akan tetapi terlepas akan hal itu, disisi lain kita dapat melihat bagaimana seharusnya kriteria seorang hakim agung dan hakim konstitusi, yang menurut Undang-Undang Dasar Pasal 24A Ayat (2): Hakim Agung harus memiliki intregitas dan kepribadian yang tidak tercela, adil, professional. Dan berpengalaman di bidang hukum. Dan juga Undang-Undang Dasar Pasal 24C Ayat (5): Hakim Konstitusi harus memiliki Intregitas dan kepribadian yang tidak tercela, adil, negarawan yang menguasai konstitusi dan ketatanegaraan, serta tidak merangkap sebagai pejabat negara. Sehingga dengan berpedoman terhadap kedua pasal tersebut, jelas bahwa seorang hakim agung dan hakim konstitusi haruslah memenuhi kriteriakriteria tersebut bukan hanya ketika diadakan seleksi didepan panitia seleksi dan ketika diadakannya wawancara tes kemampuan di depan anggota DPR, akan tetapi jauh dari itu mereka harus menjaga kriteria tersebut dan konsisten selama mereka memangku jabatan tersebut sehingga jangan sampai terulang lagi kasus yang menimpa hakim agung yang menerima suap terulang kembali, yang mana hal ini tentu saja mencoreng nama baik institusi kehakiman, mengikis kepercayaan masyarakat para pencari keadilan dan telah melanggar janji suci seorang hakim agung dan hakim konstitusi.

Kita sebagai pencari keadilan menginginkan akan kemerdekaan dan strelilnya lembaga Mahkmah Agung ini, karena sesungguhnya ketika kemerdekaan dan strelilnya institusi ini dipertanyakan maka hal ini juga pastinya akan berdampak sistemik terhadap jajaran lembaga peradilannya dibawahnya, karena sesungguhnya Mahkamah Agung adalah benteng terakhir bagi mereka pencari keadilan. Dengan demikian hakim agung dalam melaksanakn tugasnya harus sesuai prosedur dan rambu-rambu kewenangan yang telah diatur oleh Undang-Undang, karena bila melanggar maka seorang hakim agung dapat diberhentikan secara tidak hormat, sesuai dengan apa yang diatur dalam Pasal 12 UU Nomor 14 Tahun 1985 tentang Mahkamah Agung yang berbunyi: Ketua, Wakil Ketua, Ketua Muda, dan Hakim Anggota Mahkamah Agung diberhentikan dengan tidak hormat dari jabatannya oleh presiden selaku Kepala Negara atas usul Mahkamah Agung dengan alasan: (a) dipidana karena melakukan tindak pidana kejahatan; (b) melakukan perbuatan tercela; (c) terus menerus melalaikan kewajiban dalam menjalankan tugas kerjanya; (d) melanggar sumpah janji jabatan; (e) melanggar larangan yang dimaksud Pasal (10).

Sedangkan mengenai lembaga peradilan dibawahnya, jelas dengan demikian para hakim diluar hakim agung juga tidak jauh beda mengenai kode etik yang harus mereka jalankan, yakni dalam menjalankan tugasnya harus sesuai dengan prosedur dan rambu-rambu kewenangan yang diatur dalam Undang-Undang. Dimana mereka harus menepati janji suci mereka sebagai seorang hakim, bertanggung jawab atas tugasnya terhadap Negara dan Tuhan yang Maha Esa, dan menjalankan amanat mandat ini dengan sebaik-baiknya dan seksama, dan harus bebas dari campur tangan pihak kekuasaan negara lainnya, dan kebebasan dari paksaan, direktif dan rekomendasi yang datang dari pihak ekstra yudisial kecuali dalam hal-hal yang diizinkan oleh undang-undang. Dengan demikian, jelas bahwa seorang hakim dalam menjalankan tugasnya harus bebas dan merdeka namun tetap berada dalam rambu-rambu kewenangannya. Sedangkan mengenai kewenangnan dalam menjatuhkan putusan tidaklah mutlak sifatnya harus sesuai undang-undang, karena hakim sebagai penegak hukum dan keadilan wajib menggali, mengikuti dan memahami nilai-nilai hukum yang hidup dalam masyarakat berdasarkan Pancasila dengan jalan menafsirkan hukum dan mencari dasar-dasar serta asas-asas yang menjadi landasannya melalui perkara-perkara yang dihadapinya, sehingga putusannya mencerminkan perasaan keadilan bangsa dan rakyat Indonesia.

Dengan tetap berpedoman kepada aturan hukum yang berlaku, paling tidak seorang hakim harus memiliki sikap yang luhur dan baik terhadap sesama rekan, atasan, bawahan/pegawai, institusi lain, keluarga, dan masyarakat tentunya. Senada akan hal itu, seorang hakim harus memiliki peran yang diwarnai oleh tiga syarat, yaitu:

1. Tangguh, tangguh menghadapi keadaan dan kuat mental. 
2. Terampil, artinya mengetahui dan menguasai segala peraturan perundang-undangan yang sudah ada dan masih berlaku yang terkait.

3. Tanggap, artinya penyelesaian pemeriksaan perkara harus dilakukan dengan cepat, benar, serta menyesuaikan diri dengan kehendak masyarakat.

\section{Implikasi dari kedudukan hakim Ad-Hoc pada Pengadilan Tipikor (Tindak Pidana Korupsi)}

Berbicara mengenai tindak pidana korupsi (selanjutnya disebut Tipikor) untuk sekarang ini adalah perihal yang sedang hangat dibicarakan, apalagi ketika jilid ketiga KPK bergulir dengan segala sepak terjangnya telah memasukkan sedikit demi sedikit para penjahat white collar crime ke dalam jeruji besi, sebut saja seperti Nazaruddin eks Bendahara Umum DPP Demokrat, Gayus Tambunan eks pegawai pajak, Angelina Sondakh eks Anggota DPR dan lain sebagainya. Giatnya KPK dalam memberantas korupsi tidaklah segampang membalikan telapak tangan, tinjauan dan respon publik yang beraneka ragam dari yang itu bersifat masukan, kritikan, hingga hinaan tidaklah mengurangi semangat lembaga ini dalam memberantas korupsi, akan tetapi hal-hal tersebut seakan menjadi cambukan keras bagi mereka untuk selalu memberikan yang terbaik untuk Negeri yang dicintainya.

Demikian halnya ketika mereka menjadi pihak JPU KPK (Jaksa Penuntut Umum KPK) yang mana selalu dipandang oleh publik selalu terkesan setingan Pengadilan Tipikor dengan Mejelis Hakim sehingga publik memandang tidak merdeka dan bebasnya seorang Hakim Pengadilan Tipikor. Sehingga terkesan para tersangka selalu sudah dianggap sebagai terpidana, karena kemenangan selalu berpihak pada JPU KPK. Untuk mendapatkan Kondisi yang lebih objektif tersebut, maka memerlukan penanganan secara khusus yaitu bantuan tenaga hakim adhoc (non-karir) disamping hakim karir. Diharapkan dengan keberadaan hakim adhoc, pengadilan tipikor dapat menyelesaikan perkara tipikor yang melibatkan penyelenggara Negara dan diharapkan dapat mengikis dan menghilangkan kecurigaan bahwa dalam perkara tipikor Majelis Hakim kurang objektif dan selalu memenangkan pihak JPU KPK dan merugikan kepentingan terdakwa. Disamping keberadaan hakim adhoc untuk menciptakan sistem peradilan tipikor yang merdeka dan bebas serta untuk menghilangkan kondisi penilaian objektif berlebihan, keberadaannya sangatlah diperlukan mengingat maraknya tipikor yang memiskinkan negara, sehingga diperlukan jabatan hakim yang lebih banyak dan memiliki kredibilitas baik dimasyarakat untuk menyeimbangkan perluasan kewenganan pengadian tipikor di daerah-daerah luar Jabodetabek.

Sebelum melangkah lebih jauh, hendaknya kita dapat memahami apa perbedaan antara hakim karir dan hakim adhoc. Dalam Undang-Undang Nomor 49 Tahun 2009 tentang Pengadilan Tindak Pidana Korupsi Pasal 1 Ayat 1-3 dijelaskan mengenai definisi Hakim yang berbunyi:

a. Hakim adalah Hakim Karir dan Hakim Adhoc.

b. Hakim Karier adalah hakim pada pengadilan negeri, pengadilan tinggi, dan Mahkamah Agung yang ditetapkan sebagai hakim tindak pidana korupsi.

c. Hakim ad hoc adalah seseorang yang diangkat berdasarkan persyaratan yang ditentukan dalam UndangUndang ini sebagai hakim tindak pidana korupsi.

Sedangkan mengenai pengangkatan, masa jabatan dan syarat-syarat menjadi Hakim Pengadilan Tipikor, telah dijelaskan dalam Undang-Undang Nomor 49 Tahun 2009 tentang Pengadilan Tindak Pidana Korupsi Pasal 10-11 yang berbunyi:

a. Dalam memeriksa, mengadili, dan memutus perkara tindak pidana korupsi, Pengadilan Tindak Pidana Korupsi, pengadilan tinggi, dan Mahkamah Agung terdiri atas Hakim Karier dan Hakim ad hoc.

b. Hakim Karier sebagaimana dimaksud pada ayat (1) ditetapkan berdasarkan keputusan Ketua Mahkamah Agung.

c. Hakim Karier yang ditetapkan sebagaimana dimaksud pada ayat (1) selama menangani perkara tindak pidana korupsi dibebaskan dari tugasnya untuk memeriksa, mengadili, dan memutus perkara lain.

d. Hakim ad hoc pada Pengadilan Tindak Pidana Korupsi, pengadilan tinggi, dan pada Mahkamah Agung sebagaimana dimaksud pada ayat (1) diangkat dan diberhentikan oleh Presiden atas usul Ketua Mahkamah Agung.

e. Hakim ad hoc sebagaimana dimaksud pada ayat (4) diangkat untuk masa jabatan selama 5 (lima) tahun dan dapat diangkat kembali untuk 1 (satu) kali masa jabatan.

Dan bunyi Pasal 11 adalah sebagai berikut:

Untuk dapat ditetapkan sebagai Hakim Karier, calon harus memenuhi persyaratan sebagai berikut:

a. Berpengalaman menjadi Hakim sekurang-kurangnya selama 10 (sepuluh) tahun; 
b. Berpengalaman menangani perkara pidana;

c. Jujur, adil, cakap, dan memiliki integritas moral yang tinggi serta reputasi yang baik selama menjalankan tugas;

d. Tidak pernah dijatuhi hukuman disiplin dan/atau terlibat dalam perkara pidana;

e. Memiliki sertifikasi khusus sebagai Hakim tindak pidana korupsi yang dikeluarkan oleh Mahkamah Agung; dan

f. Telah melaporkan harta kekayaannya sesuai dengan ketentuan peraturan perundang-undangan.

Sedangkan bunyi Pasal 12 adalah sebagai berikut:

Untuk dapat diangkat sebagai Hakim ad hoc, calon harus memenuhi persyaratan sebagai berikut:

a. Warga negara Republik Indonesia;

b. Bertakwa kepada Tuhan Yang Maha Esa;

c. Sehat jasmani dan rohani;

d. Berpendidikan sarjana hukum atau sarjana lain dan berpengalaman di bidang hukum sekurang-kurangnya selama 15 (lima belas) tahun untuk Hakim ad hoc pada Pengadilan Tindak Pidana Korupsi dan pengadilan tinggi, dan 20 (dua puluh) tahun untuk Hakim ad hoc pada Mahkamah Agung;

e. Berumur sekurang-kurangnya 40 (empat puluh) tahun pada saat proses pemilihan untuk Hakim ad hoc pada Pengadilan Tindak Pidana Korupsi dan pengadilan tinggi, dan 50 (lima puluh) tahun untuk Hakim ad hoc pada Mahkamah Agung;

f. Tidak pernah dipidana karena melakukan kejahatan berdasarkan putusan pengadilan yang telah memperoleh kekuatan hukum tetap;

g. Jujur, adil, cakap, dan memiliki integritas moral yang tinggi serta reputasi yang baik;

h. Tidak menjadi pengurus dan anggota partai politik;

i. Melaporkan harta kekayaannya;

j. Bersedia mengikuti pelatihan sebagai Hakim tindak pidana korupsi; dan

k. Bersedia melepaskan jabatan struktural dan/atau jabatan lain selama menjadi Hakim ad hoc tindak pidana korupsi.

Dengan memperhatikan bunyi-bunyi pasal diatas, jelas kita dapat memahami bahwa tidak terdapat perbedaan yang principal antara syarat-syarat hakim karir dan hakim adhoc. Karena pada hakekatnya, keberadaan hakim adhoc sangatlah diperlukan mengingat kompleksitas perkara tipikor, baik yang menyangkut modus operandi, pembuktian, maupun luasnya cakupan tipikor antara lain di bidang keuangan dan perbankan, pasar modal, pengadaan barang dan jasa pemerintah. Sehingga demikian, Panitia Seleksi Mahkamah Agung dalam penyeleksian hakim adhoc lebih menitik beratkan pada mereka yang tidak hanya berpendidikan hukum pidana, namun lebih dari itu kepada mereka yang berpengalaman dalam bidang hukum perekonomian, pembuktian, hukum adminsitrasi Negara, dan hukum pajak. Hakim adhoc sangatlah dibutuhkan karena kurangnya pengalaman hakim-hakim karir apabila menghadapi kasus yang terlalu kompleks, sehingga membutuhkan pengetahuan yang ekstra diluar ilmu hukum.

Dengan demikian Ketua Pengadilan akan memilih hakim adhoc berdasarkan daftar nama hakim adhoc yang disesuaikan dengan keahlian hakim adhoc tersebut. Jadi ada daftar registrasi hakim adhoc spesialisasi yang ditentukan berdasarkan keahliannya, misalnya perkara tindak pidana korupsi yang berkaitan dengan perpajakan, maka Ketua Pengadilan akan menetapkan hakim adhoc spesialisasi dari daftar hakim adhoc yang ahli perpajakan, dan seterusnya. Yang juga menjadi isu pokok pembahasan, adalah mengenai komposisi Majelis Hakim dalam persidangan, yang seharusnya menurut penulis akan lebih baik apabila Ketua Pengadilan dalam menentukannya harus sesuai prosedur yang proporsional dan komposisinya sesuai dengan kepentingan pemeriksaan perkara untuk menghindari dikotomi proses dan integritas antara hakim karir dan hakim adhoc. Sedangakan mengenai kewenangan hakim adhoc tidaklah beda dengan hakim karir, karena pada dasarnya dalam Undang-Undang Nomor 49 Tahun 2009 tentang Pengadilan Tindak Pidana Korupsi yang dimaksud dengan hakim adalah hakim karir dan hakim adhoc sehingga keduanya tidak memiliki kewenangan yang berbeda, hal ini dipertegas dalam kewenangannya dalam memeriksa, mengadili, dan memutus tindak pidana korupsi dalam pasal 6 yang berbunyi: Pengadilan Tindak Pidana Korupsi sebagaimana dimaksud dalam Pasal 5 berwenang memeriksa, mengadili, dan memutus perkara:

a. Tindak pidana korupsi;

b. Tindak pidana pencucian uang yang tindak pidana asalnya adalah tindak pidana korupsi; dan/atau

c. Tindak pidana yang secara tegas dalam undang-undang lain ditentukan sebagai tindak pidana korupsi.

Dan pasal 7 yang berbunyi: Pengadilan Tindak Pidana Korupsi pada Pengadilan Negeri Jakarta Pusat juga berwenang memeriksa, mengadili, dan memutus perkara tindak pidana korupsi sebagaimana dimaksud dalam Pasal 6 yang dilakukan oleh warga negara Indonesia di luar wilayah negara Republik Indonesia. 
Selain memiliki kewenangan memerikasa, mengadili, dan memutus perkara tidak pidana korupsi, hakim adhoc juga memiliki kewenangan memeriksa perkara tidak pidana pencucian uang yang tindak pidana asalnya adalah tindak pidana korupsi. Jadi disini korupsi sebagai tindak pidana asal yang sering disebut sebagai predicate crimes. Tak kalah pentingnya bahwa peran dan kewenangan hakim adhoc spesialisasi dalam kaitan pasal 6 huruf c kewenanan pengadilan tipikor untuk menangani tindak yang secara tegas dalam undang-undang lain ditentukan sebagai tindak pidana korupsi. Mengingat peran hakim karir yang cukup besar dan hakim adhoc merupakan penunjang peran pengadilan tipikor, karenanya hakim adhoc diwajibkan mengikuti pendidikan khusus tipikor sebagai hakim adhoc yang bersertifikasi. Mahkamah Agung sudang memberikan jawaban antisipasinya berupa keberadaan hakim karir bersertifikasi dengan mengadakan pendidikan tindak pidana korupsi.

\section{PENUTUP}

\section{Simpulan}

Keberadaan hakim adhoc adalah untuk menciptakan sistem peradilan tipikor yang merdeka dan bebas serta untuk menghilangkan kondisi penilaian objektif berlebihan, keberadaannya sangatlah diperlukan mengingat maraknya tipikor yang memiskinkan negara, sehingga diperlukan jabatan hakim yang lebih banyak dan memiliki kredibilitas baik dimasyarakat untuk menyeimbangkan perluasan kewenganan pengadian tipikor di daerah-daerah luar Jabodetabek. Dengan demikan keberadaan hakim adhoc sangatlah diperlukan mengingat kompleksitas perkara tipikor, baik yang menyangkut modus operandi, pembuktian, maupun luasnya cakupan tipikor antara lain di bidang keuangan dan perbankan, pasar modal, pengadaan barang dan jasa pemerintah.

\section{DAFTAR PUSTAKA}

\section{Buku}

Alatas, Syed Husein, 1983. Sosiologi Korupsi: Sebuah Penjelajahan Dengan Data Kontemporer, LP3ES Jakarta

Adji, Idriyanto Seni, 2009. Korupsi dan Penegakan Hukum. Diadit Media Jakarta

Danil, elwi 2011. Korupsi: Konsep, Tindak Pidana, dan Pemberantasannya. Rajawali Press Jakarta

Friedman, Lawrence M 1984., Element Of a Legal System, New York London: W.W Norton \& Company

Syamsudiin, Aziz, 2009. Tindak PIdana Khusus, Sinar Grafika, Jakarta

Supriadi, 2008 Etika dan Tanggung Jawab Profesi Hukum Di Indonesia, Sinar Grafika Jakarta

Adam Chzaawi. 2005. Hukum Pidana Meteriil dan Formil Korupsi di Indonesia. Bayumedia. Malang

Ahmad Mujahidin. 2007. Peradilan Satu Atap di Indonesia. PT Refika Aditama. Bandung

A.Mukti Arto. 2001. Konsepsi Ideal Mahkamah Agung Redifinisi Peran dan Fungsi Mahkamah Agung untuk Membangun Indonesia Baru. Pustaka Pelajar Yogyakarta

Bambang Sutiyoso dan Sri Hastuti Puspita Sari. 2005. Aspek-Aspek Perkembangan Kekuasaan Kehakiman. Yogyakarta : UII Press Yogyakarta.

C. S. T. Kansil dan Christine S. T. S. Kansil. 2000. Pengantar Ilmu Hukum Semester Ganjil. Balai Pustaka. Jakarta

Ermansjah Djaja. 2008. Memberantas Korupsi Bersama KPK Komisi Pemberantasan Korupsi Kajian Yuridis Normatif UU Nomor 31 Tahun 1999 juncto UU Nomor 20 Tahun 2001 Versi UU Nomor 30 Tahun 2002. Sinar Grafika. Jakarta

\section{Undang-Undang}

Undang-Undang Dasar 1945.

Undang-Undang Nomor 20 Tahun 2001 Tentang Pemberantasan Tindak Pidana Korupsi.

Undang-Undang Nomor 46 Tahun 2009 Tentang Pengadilan Tindak PidanaKorupsi.

Undang-Undang Nomor 48 Tahun 2009 Tentang Kekuasaan Kehakiman 